\title{
Proqram Məhsullarında Xətaların Aşkarlanması Metodu
}

\author{
Fərqanə Abdullayeva \\ AMEA İnformasiya Texnologiyaları İnstitutu, Bakı, Azərbaycan \\ farqana@iit.ab.az
}

\begin{abstract}
Xülasə- Proqram təminatının keyfiyyətinin qiymətləndirilməsində mühüm amillərdən biri proqram modullarında xətaların aşkarlanmasıdır. Təqdim olunan işdə xətaların aşkarlanması üçün klassifikatorlar ansamblına əsaslanan model təklif olunur. Xətaların aşkarlanması kriteriyalara qoyulmuş sərhəd qiymətləri əsasında təmin edilir. Burada xətaları aşkarlamaq üçün PROMISE proqram mühəndisliyi reyestrindən əldə edilmiş KC2 verilənlər bazasından istifadə edilmişdir. Eksperimentlər Matlab və Weka proqramları vasitəsi ilo aparılmışdır. Metodun eksperimental tədqiqi nəticəsində $\mathbf{0 . 8 8 \%}$ aşkarlama dəqiqliyi əldə edilmișdir.
\end{abstract}

Keywords- proqram mühəndisliyi, xəta, maşın tolimi, Isolation Forest, Random Forest

\section{GİRIŞ}

Proqram sistemlərinin mürəkkəb quruluşa malik olması bu sistemlərdə yol verilmiş xətaların aşkarlanması prosesini olduqca çətinləşdirir. Layihə menecerləri proqram məhsullarında xətaları proqnozlaşdıran metodlardan istifadə etməklə adətən bu xətaları sistem test edilməzdən əvvəl aşkarlaya bilir. Proqram məhsullarında xətaların aşkarlanması üçün qərar ağacı, loqarifmik reqresiya, qeyri-səlis məntiq, neyron şəbəkələri, genetik alqoritm kimi məşhur aparatlara əsaslanan vasitələr təklif edilmişdir [1]. Bu yanaşmaların test edilməsi prosesində verilənlər bazasında kənaraçıxmaların (outlier) olması faktı nəzərə alınmamışdır. $\mathrm{Bu}$ səbəbdən verilənlər bazasında kənaraçıxma olduqda mövcud metodların aşkarlama dəqiqliyi olduqca azalır.

Kənar element (outlier) şablonun real elementlərindən fərqli qiymətlər alan elementlərdir [2]. Yəni verilənlər obyektinin qiyməti əlamət üçün təyin edilmiş sərhəd qiymətlərini aşarsa lakin verilənlər obyektinin sinifi xətasız kimi təsnifatlaşdırılarsa, həmin element kənar element kimi qəbul olunur. Və əksinə əgər verilənlər obyektinin qiyməti əlamət üçün təyin edilmiş sərhəd qiymətlərindən aşağıdırsa lakin verilənlər obyektinin sinifi xətalı kimi təsnifatlaşdırılarsa, həmin element kənar element kimi qəbul olunur.

Sistemin proqram məhsullarında yol verilmiş xətaların aşkarlanmasında dəqiqliyi yüksəltmək üçün klassifikatorların birləşdirilməsi zəruri hesab olunur [3]. Təqdim olunan məqalədə proqram məhsullarında xətaların aşkarlanma dəqiqliyini artırmaq üçün klassifikatorlar ansamblına əsaslanan yanaşma təklif edilir. Xəta verilənləri - proqram məhsullarının qiymətləndirilməsi üçün yaradılmış verilənlər bazalarında (məsələn, KC2) xətall və xətasız kimi iki sinifdə təsvir edilmişdir [4].
Təklif edilmiş metodun eksperimental yoxlanması WEKA proqramında və KC2 verilənlər bazasının üzərində aparılmışdır.

\section{XӘTALARIN AŞKARLANMASI ÜÇÜN OLAMOTLOR VEKTORU}

Proqram məhsullarında xətaları aşkarlamaq üçün aşağıdakı əlamətlər və uyğun sərhəd qiymətləri istifadə edilir [4,5]:

- Kodun uzunluğu (lines of code - LoC). Kodun sətirlərinin ümumi sayı nəzərdə tutulur;

- Dövri mürəkkəblik (cyclomatic complexity - CC). Proqramın struktur cəhətdən mürəkkəbliyinin ölçülməsi meyarıdır. Proqramın axın qrafindakı (flow graph) asılı olmayan yolların ümumi sayı ilə ölçülür;

- Osas mürəkkəblik (essential complexity - EsC). Proqramda "if-then-else" şərt və "while" dövr prosesinin yaxşı strukturlaşdırılmasını tələb edir. Proqramda "goto" operatorundan istifadə edilməsi EsC qiymətini artıran amildir;

- Unikal operator (unique operator - UOpr). Proqramda unikal operatorların ümumi sayıdır. Әgər eyni bir operator bir neçə dəfə istifadə edilibsə, bu operator bir dəfə nəzərə alınır;

- Unikal operand (unique operand - UOpnd). Unikal operandların ümumi sayıdır. Ogər eyni bir operand bir neçə dəfə istifadə edilibsə, bu operand bir dəfə nəzərə alınır;

- Ümumi operator (total operator - TOpr). Modulda rast gəlinən operatorların ümumi sayı. Operatorlara misal olaraq məntiqi operatorları, riyazi əməliyyatları və hər bir açar sözü (return, sizeof və s.) göstərmək olar;

- Ümumi operand (total operand - TOpnd). Modulda rast gəlinən operandların ümumi sayı nəzərdə tutulur.

İntegrasiya olunmuş Proqram Metrikaları Korporasiyası (Integrated Software Metrics, Inc.) xətaları aşkarlamaq üçün metrikalara sərhəd qiymətləri müəyyən etmişdir (cədvəl 1) [6].

CəDVӘL 1. METRIKALAR VӘ SəRHəD QIYMӘTLӘRİ

\begin{tabular}{|l|c|c|}
\hline \multicolumn{1}{|c|}{ Metrika } & Qisaltma & Sərhəd qiyməti \\
\hline Kodun uzunluğu & LoC & 65 \\
\hline Dövri mürəkkəblik & CC & 10 \\
\hline Osas mürəkkəblik & EsC & 4 \\
\hline Unikal operator & UOpr & 40 \\
\hline Unikal operand & UOpnd & 25 \\
\hline Ümumi operator & TOpr & 125 \\
\hline Ümumi operand & TOpnd & 70 \\
\hline
\end{tabular}


Təqdim olunan məqalədə xətaların aşkarlanması üçün cədvəl 1-də verilən sərhəd qiymətləri istifadə edilir.

\section{XӘTALARIN AŞKARLANMASI METODU}

Proqram məhsullarında xətaların aşkarlanması üçün təklif edilmiş yanaşmanın qərar qəbulu sisteminin arxitekturu şəkil 1də təsvir edilmişdir.

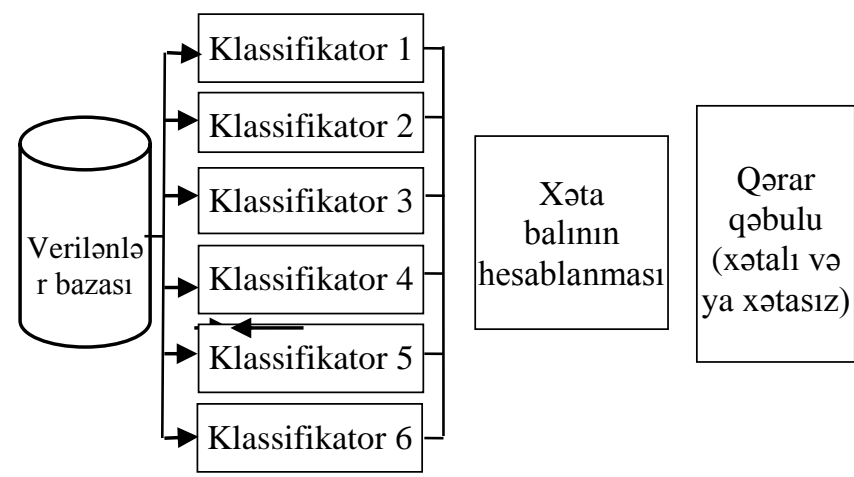

Şəkil 1. Proqram məhsullarında xətaların aşkarlanması modeli

Şəkil 1-dən göründüyü kimi qərar qəbulu sistemi alt1 klassifikatordan ibarətdir. Burada bu klassifikatorların hər birinin fərdi qərarı kollaborativ qərar vermək üçün birləşdirilir.

$\mathrm{Bu}$ klassifikatorları birləşdirməkdə məqsəd sistemin proqram məhsullarında yol verilmiş xətaları aşkarlama keyfiyyətini yüksəltməkdir. Bu prosesi həyata keçirmək üçün hər bir klassifikator təsnif edilmiş verilənlər vasitəsi ilə öyrodilir.

Fərz edək ki, $C=\left\{c_{i} \mid 1 \leq i \leq n\right\}$ öyrədilən klassifikatorlardır və $D=\left\{d_{i} \mid 1 \leq i \leq n\right\}$ sayda qərar qəbulu modeli qurur. Hər bir $i$-ci qərarqəbuletmə $d_{i}$ modeli test edilən $x_{i}$ elementinə binar qiymət ( 0 və ya 1 ) verir, $d_{i}=\left(x_{i}\right): v_{i} \cdot v_{i}-$ nin binar qiyməti 1 olduqda $x_{i}$ elementi xətalı kimi qiymətləndirilir, əks halda xətasız kimi qiymətləndirilir. Belə olduqda xəta balı aşağıdakı düsturla hesablanır:

$$
x_{i}=\frac{\sum_{j=1}^{n} d_{j}\left(x_{i}\right)}{n}
$$

burada $n$ xəta balının hesablanmasında iștirak edən qərar qəbuletmə modellərinin sayıdır. Verilənlər bazasının elementlərinin sinifi, xətalı və ya xətasız, aşağıdakı düsturla hesablanır:

$$
\operatorname{Class}\left(x_{i}\right)=\left\{\begin{array}{lc}
x_{i} \geq \rho & \text { qüsurlu }=1 \\
\text { eks halda } & \text { qüsursuz }=0
\end{array} .\right.
$$

burada $\rho$ - qərar qəbuletmə modellərinin test edilən $x_{i}$ elementini xətasız kimi qiymətləndirmək üçün verdikləri balın faiz qiymətidir. Məsələn, əgər $\rho$ sərhəd qiyməti 1 götürüldükdə, və əgər iştirak edən qərar qəbuletmə modellərinin hamısı eyniliklə elementin xətalı olduğunu qəbul etməsə, test edilən element xətalı kimi qəbul olunmayacaqdır.

Misal. Fərz edək ki, öyrədilən beş klassifikator götürülmüşdür $C=\left\{c_{1}, c_{2}, c_{3}, c_{4}, c_{5}\right\}$, bu klassifikatorlar qərar qəbulu modellərini $D=\left\{d_{1}, d_{2}, d_{3}, d_{4}, d_{5}\right\}$ qurmaq üçün təsnif edilmiş verilənlərlə öyrədilmişdir, və fərz edək ki, test edilən $x_{i}$ elementinə qərar qəbuletmə modelləri tərəfindən uyğun olaraq $1,1,0,1,1$ balları verilmişdir. Onda $x_{i}$ elementinin xəta balı aşağıdakı kimi hesablanar:

$$
x_{i}=\frac{1+1+0+1+1}{5}=\frac{4}{5}=0.80
$$

burada sərhəd qiymətinin $\rho=0.6$ qiymətində $x_{i}$ elementinin xəta olduğu fərz edilərsə, onda ən azı üç qərar qəbuletmə modelinin $x_{i}$ elementini xəta kimi qiymətləndirməsi kifayət edər ki, element xəta hesab olunsun.

\section{TӘKLİF OLUNAN METODUN EKSPERIMENTAL TODQİİ}

Eksperimentlərin aparılması üçün NASA KC2 verilənlər bazasından istifadə edilmişdir [4].

Proqram məhsullarında qüsürlu elementlərin aşkarlanması üçün BFTree (Best First Tree), PART, IBk, NNg, IsolationForest, RandomForest alqoritmləri istifadə edilmişdir.

Təklif edilmiş yanaşmanın effektivliyini qiymətləndirmək üçün doğru müsbət aşkarlama əmsalı (true positive rate - TP), yalnış müsbət aşkarlama əmsalı (false positive rate - FP), Fölçü (F-measure), doğruluq (acuracy), dəqiqlik (precision), tamlıq (recall) parametrləri istifadə edilmişdir. Klassifikasiya prosesində istifadə edilən xətalar matrisi (confusion matrix) cədvəl 2-də təsvir edilmişdir.

\section{CODVӘL 2. XӘTALAR MATRISII}

\begin{tabular}{|c|c|c|}
\hline \multirow{2}{*}{\begin{tabular}{c}
$|c|$ \\
\cline { 2 - 3 }
\end{tabular}} & \multicolumn{2}{|c|}{ Real tosnif olunmuş verilənlər } \\
\hline \multirow{2}{*}{$\begin{array}{c}\text { Proqnoz edilən təsnif olunmuş } \\
\text { verilənlər }\end{array}$} & TP & Yox \\
\cline { 2 - 3 } & FN & TN \\
\hline
\end{tabular}

Təklif edilmiş modelin effektivlik parametrləri aşağıdakı kimi hesablanır:

8) Dəqiqlik (precision). Çeşidlənmiş davranış sırasında doğru aşkarlanmış normal davranışın faiz dərəcəsi.

$$
\text { Precision }=T P /(T P+F P)
$$

9) Tamlıq (recall). Bütün normal davranışlar sırasında aşkarlanmış normal davranışın faiz dərəcəsi.

$$
\text { Recall }=T P /(T P+F N)
$$

10) Yalnış müsbət hallar (false positive rate $-F P R$ ).

$$
F P R=F P /(F P+T N)
$$

11) $\quad F$-ölçü ( $F$-measure). 


$$
F-\text { measure }=2 * \frac{\text { Precision }^{*} \text { Recall }}{\text { Precision }+ \text { Recall }}
$$

12) Doğru müsbət hallar (True Positives - TP).

$$
T P R=T P / \text { positive }
$$

13) Doğru mənfi hallar (True Negatives - TN).

$$
T N R=T N / \text { negative }
$$

14) Yalnış mənfi hallar (False Negatives - FN).

$$
F N R=F N /(F N+T P)
$$

15) Yalnış aşkarlanma omsalı (False discovery rate FDR).

$$
F D R=F P /(F P+T P)
$$

16) Doğruluq (accuracy).

$$
\text { Accuracy }=(T P+T N) /(P+N)
$$

KC2 verilənlər bazası üzərində aparılmış eksperimentlərin nəticəsi cədvəl 3-də təsvir edilmişdir. Burada müxtəlif metodların $\mathrm{KC} 2$ verilənlər bazası üzərində test nəticələri daxil edilmişdir.

CODVӘL 3. TOKLIF EDILLMIS YANASMANIN MÖVCUD METODLARLA MÜQAYİSəSİ (KC2 VERILİNLӘR BAZASI) (FAİLZ)

\begin{tabular}{|l|c|c|c|c|}
\hline & BFTree & $\mathbf{J 4 8}$ & $\begin{array}{c}\text { MultilayerPe } \\
\text { rseptron }\end{array}$ & $\begin{array}{c}\text { Klassifikatorlar } \\
\text { ansamblı }\end{array}$ \\
\hline TP & 0.816 & 0.803 & 0.711 & 0.882 \\
\hline FP & 0.243 & 0.243 & 0.206 & 0.150 \\
\hline F-measure & 0.756 & 0.748 & 0.711 & 0.843 \\
\hline $\begin{array}{l}\text { False discovery } \\
\text { rate }\end{array}$ & 0.1842 & 0.197 & 0.289 & 0.1184 \\
\hline Acuracy & 0.7814 & 0.7760 & 0.7596 & 0.8634 \\
\hline Precision & 0.705 & 0.701 & 0.711 & 0.8816 \\
\hline Recall & 0.816 & 0.803 & 0.711 & 0.882 \\
\hline
\end{tabular}

Cədvəl 3-dən göründüyü kimi ayrı-ayrı klassifikatorların nöqsanları aşkarlama dəqiqliyi bütün göstəricilər üzrə klassifikatorlar ansamblının aşkarlama dəqiqliyindən olduqca aşağıdır. Belə ki, TP göstəricisi BFTree, J48, Multilayer Perseptron alqoritmləri üçün uyğun olaraq $0.816,0.803,0.711$ təşkil etdiyi halda klassifikatorlar ansamblı üçün bu qiymət $0.882 \%$ təkil etmişdir. Bundan əlavə təklif edilmiş metodun yanlış aşkarlama dəqiqliyi də məqsədəuyğun alınmışdır. Belə ki, klassifikatorlar ansamblında FP-nin qiyməti $0.150 \%$, digər alqoritmlərdə isə bu qiymət olduqca böyük alınmışdır. Bundan əlavə metodun aşkarlama dəqiqliyində də yaxşı nəticə alınmışdır. Belə ki, bu göstərici üzrə BFTree 0.705\%, J48 $0.701 \%$, Multilayer Perseptron 0.711, klassifikatorlar ansambli 0.8816 faiz təşkil etmişdir.

Şəkil 2-də klassifikatorlar ansamblının KC 2 verilənlər bazasının LoC və $\mathrm{V}(\mathrm{g})$ parametrlərinə nəzərən nəticəsi vizual olaraq təsvir olunmuşdur. Şəkildə təsvir olunmuş göy rəngli "+" işarəsi xətasız (not-defected), qurmızı rəngli romb işarəsi xətalı (defected), çəhrayı rəngli nöqtələr kənaraçıxmaları göstərir.

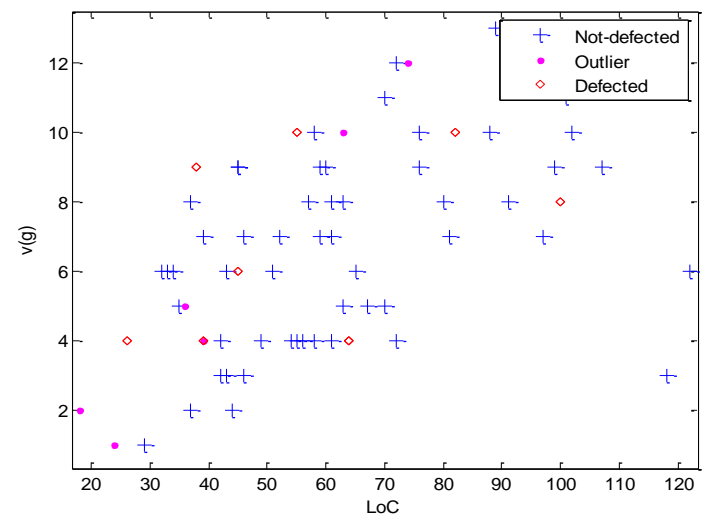

Şəkil 2. KC2 verilənlər bazasının təsnifatlaşdırılması

Şəkil 3-də nöqsanların aşkarlanması prosesinin vizual təsviri verilmişdir. Şəkildən göründüyü kimi təklif edilmiş metodda aşkarlama zamanı çox az sayda kənaraçıxma alınmışdır. Bu səbəbdən təklif edilmiş metodun aşkarlama dəqiqliyi digər metodlarla müqayisədə daha yüksək alınmışdır.

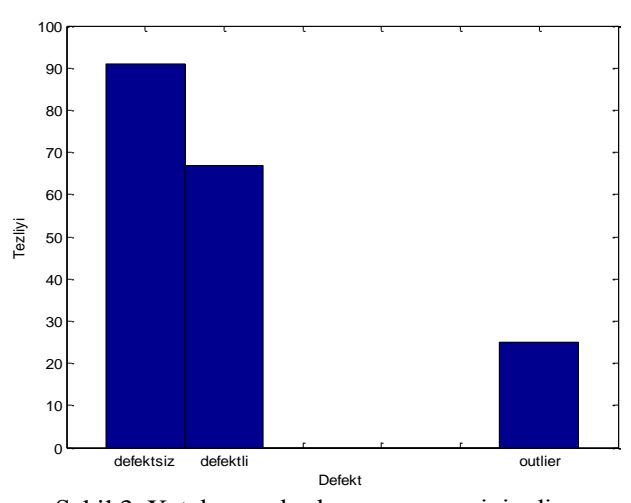

Şəkil 3. Xətaların aşkarlanması prosesinin diaqramı

Şəkil 4-də klassifikatorlar ansamblının BFTree alqoritmi ilə effektivliyinin müqayisəsi təsvir edilmişdir. Buradan aydın şəkildə görünür ki, klassifikatorlar ansablı BFTree alqoritminə nəzərən yüksək effektivliyə malikdir.

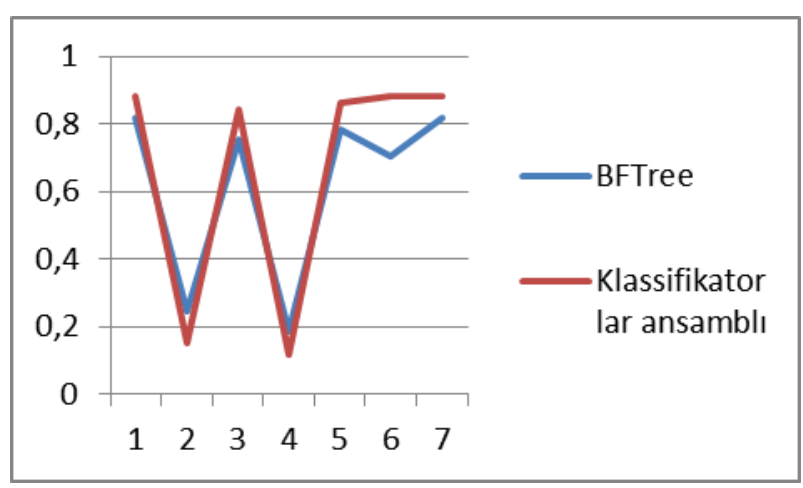

Şəkil 4. Alqoritmlərin effektivliyinin müqayisəsi 
Proqram məhsullarında defektlərin aşkarlanması sahəsində eksperimentlərin aparılması üçün CM1, PC!-1107, JM1-10876, KC1-2107 verilənlər bazaları da istifadə oluna bilər.

\section{NəTICO}

Məqalədə açıq verilənlər bazasından istifadə edərək proqram məhsullarında xətaların aşkarlanması üçün üsul təklif olunmuşdur. Eksperimentlərin nəticəsi təklif edilmiş metodun bir sıra qiymətləndirmə metrikalar üzrə aşkarlama dəqiqliyinə görə məşhur BFTree, J48 və MultilayerPerseptron alqoritmlərindən üstünlük təşkil etdiyini göstərmişdir. Burada istifadə olunan verilənlər bazasının sinifləri əvvəlcədən məlum olduğundan təklif edilmiş modeldə öyrədilən (supervised) maşın təlimi alqoritmləri istifadə edilmişdir.

\section{ӘDӘBIYYYT}

[1] C. Catal, B. Diri, "Investigating the effect of dataset size, metrics sets and feature selection techniques on software fault prediction problem," Information Sciences, 2009, vol. 179, no. 8, pp. 1040-1058.

[2] J.V. Hodge, J. Austin, "A survey of outlier detection methodologies," 2004, vol. 22, no. 2, pp 85-126.

[3] Р.М. Алыгулиев, Я.Н. Имамвердиев, Ф.Д. Абдуллаева, “Обнаружение аномалий в облачных BIG DATA данных," XIII-ая международная конференция «Оптико-электронные приборы и устройства в системах распознавания образов, обработки изображений и символьной информации», 2017, в печати.

[4] KC2, NASA metrics data program, PROMISE software engineering repository, 2004, http://promise.site.uottawa.ca/SERepository/datasetspage.html.

[5] P. Hea, B. Lic, X. Liua, J. Chenb, Y. Mab, "An empirical study on software defect prediction with a simplified metric set," Information and Software Technology, 2015, vol. 59, pp. 170-190.

[6] C. Cagatay, D. Banu, "A fault detection strategy for software projects," Technical Gazette, 2013, vol. 20, no. 1, 7 p. 